\section{ECONOMICS}

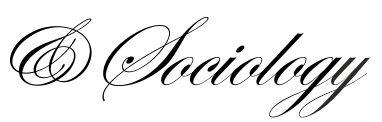

Nataliia Skopenko, Julia Sagaydack, Specific Features of Development of Ecological Entrepreneurship in Ukraine, Economics \& Sociology, Vol. 6, No 2, 2013, pp. 28-38. DOI: 10.14254/2071-789X.2013/6-2/3

\title{
SPECIFIC FEATURES OF DEVELOPMENT OF ECOLOGICAL ENTREPRENEURSHIP IN UKRAINE
}

\begin{abstract}
The article is dedicated to a problem of establishment and development of ecological entrepreneurship in Ukraine. The authors pay attention to the methodological basis of ecological entrepreneurship, define the category "ecological entrepreneurship", and address the specific features of this phenomenon. The main problems of the agricultural sector of Ukraine as a prospect for ecological entrepreneurship development are outlined in the paper: the destruction of soils, lack of land cultivation, pollution and more. An important element of ecological entrepreneurship development is production ecologization, which will be implemented as a component within the framework of conception of sustainable development. Eco-destruction processes, which prevent progress of ecological entrepreneurship in Ukraine, are analyzed.
\end{abstract}

DOI: $10.14254 / 2071-$

789X.2013/6-2/3

JEL Classification: Q57

Keywords: ecological entrepreneurship, ecologization of economy, pollution, ecological problems of Ukraine.

\section{Introduction}

An ecological entrepreneurship is a new sphere of scientific interests of researchers. The deepening of market relations and sustainable development ideas are changing the scientific views and directions of modern entrepreneurship development. Managers may recognize the need for transition to a new model of economic management in accordance with the market requirements and consumer demand. However, there has been no uniform determination of ecological entrepreneurship so far; methods for evaluation of ecological activity of the enterprises are absent. Researchers have repeatedly emphasized that current economic models and behaviour would lead to social collapse. Thus, development of a new economic model, ecological entrepreneurship theory, is a high priority. The need for introducing the newest approaches and methods of economic management is widely discussed and highlighted among the researches. The papers by V. Basylevych, O. Veklych, T. Galushkina, B. Danylyshyn, M. Dolishniy, L. Melnyk, V. Mischenko and others are dedicated to the problems of establishing ecological entrepreneurship in Ukraine (Basylevych, 2010, p. 6; Veklych, 2003; Galushkina, 2000; Danylyshyn, 1999; Melnyk L., Melnyk O., Burlakova, 2011). 
Questions of ecological policy in Ukraine, regarding concerns, consequences, and resource potential are addressed in papers by L. Rudenko, Y. Golik, A. Tolstoukhov, M. Zgurovs'kyi.

However, the relevance of said issues in focus is inexhaustible, since it touches upon vitally important questions, such as ecological safety of the state, health of the nation, life of future generations. Taking this into account, the problems of organization and development of ecological entrepreneurship in Ukraine are especially noteworthy. The main object of the article is to determine the specific features of ecological entrepreneurship establishment in Ukraine and its development in domestic economy. In accordance with the object to be achieved the following tasks are set:

- to define the methodological basis of ecological entrepreneurship development in Ukraine;

- to study the specific features of organization of the ecological entrepreneurship sector in the domestic economy;

- to analyze the perspective directions of ecological entrepreneurship development;

- to rationalize the ways of implementing the main programs and finding solutions to the tasks of ecological entrepreneurship.

General scientific and special methods are used in a paper to study processes and phenomena. Research methods include: logic, economic analysis, expert estimations, comparison method, systems analysis, synthesis, induction, deduction, and analogies. The theoretical basis of research is the fundamental provisions of economic theory, scientific researches of ecological enterpreneurship, efficiency of companies' activity, management theory of complex social and economical systems, and strategic management.

However, there is a significant lack of information on ecological enterpreneurship development in Ukraine, sometimes even a complete absence, so statistical data from accessible information sources are used in the paper.

\section{The methodological basis of the ecological enterpreneurship}

The Organization for Economic Cooperation and Development (OECD) and EUROSTAT, defines an ecological enterpreneurship ("green" business) as an activity for producing of goods and providing services to estimate, prevent, limit, minimize or eliminate the ecological damage to water, air and soil, as well as problems-related to waste, noise and ecological systems. This activity includes cleaner technologies, goods and services, which reduce environmental risk and minimize environment pollution and utilization of resources (OECD/EUROSTAT, 1999, p. 9).

Countries worldwide call the same phenomenon different names. In most European countries the most common term is "green business"; in Ukraine it is "ecological enterpreneurship". Neither scientific nor legal literature have a uniform interpretation of the term ecological enterpreneurship. The Commercial Code of Ukraine gives a legal definition of the term enterprise as independent, initiative, systematic, at the own risk, economic activity, which is carried out by economic entities (entrepreneurs) in order to achieve economic and social results and to receive profit (http://zakon. rada. gov.ua).

Most Ukrainian researchers interpret the ecological enterpreneurship as a type of entrepreneurial activity that produces goods, implements works and provides services for environmental protection (Basylevych, 2010, p. 6; Veklych, 2003; Galushkina, 2000; Danylyshyn, 1999; Melnyk L., Melnyk O., Burlakova, 2011).

We define an ecological entrepreneurship as follows: an entrepreneurial activity involving the production of goods and provision of services; the implementation of works that 
do not harm the environment; and which contribute to environmental preservation and renewal while meeting the consumers' needs for ecological products.

Ecological entrepreneurship has the following features:

- The target setting is to harmonize relations between human and nature, to protect the environment;

- Principle activity is a production of goods, implementation of works and provision of services for special environmental protection;

- Linkage of activity to the rational use, maintenance, renewal and protection of natural resources, ecological safety;

- Criterion of activity - not wasteful in production processes;

- Basic direction of development is an ecological quality of products, works, services;

- Developed scientific component of ecological activity (use of the results of modern scientific researches, methods, instruments, technologies etc.);

- Introduction of ecological management with consideration for the specific nature and need for ecological production;

- Ecological education and culture of personnel;

- Functioning of ecological products, works, services market;

- Functioning of economic entities of any legal form of ownership and management;

- Activity within the framework of current legislation, including environmental. Entrepreneurs engaged in production of environmentally oriented goods, implementation of works and provision of services should set the following main tasks:

- Introduction of production of new environmentally friendly goods, works and services, effective waste-free or low-waste ecological technologies;

- Reducing the amount of use of material and energy resources;

- Reduction and efficient recycling, waste recycling;

- Acquiring new knowledge, skills, recruitment of skilled staff in the fields of economy and ecology;

- Increase of investment attractiveness of "green" business;

- Creation of new "ecological" jobs, safe working conditions and accommodation;

- Raising environmental awareness and culture;

- Improvement of company's image as socially and ecologically responsible one;

- Reduction of ecological risks, negative impact on the environment;

- Preservation and environmental protection (Kupalova, 2011, p. 37).

Effective development of ecological entrepreneurship is only possible under certain social and economic conditions, stable economic and social policy. However, one of the causes of a low activity of enterpreneurs in the field of green business is the lack of national strategy of ecological enterpreneurship development. World experience shows (for example in Germany) that effectiveness of such type of activity increases with a full national support, assistance in problem-solving, and clearly defined guidelines. Since an ecological entrepreneurship is crucial to society, one of the main tasks of the state is to provide a legislative framework for the legal norms of its functioning. This sector must become a priority branch of economy. Currently, the questions of ecological enterpreneurship development are legislated only fragmentary. Since no legal interpretation of the ecological entrepreneurship exists, it is necessary to define the basic principles of functioning and development of this sector in Ukraine.

A major step forward is a formation of the Law of Ukraine "On basic principles (strategy) of the State Environmental Policy of Ukraine for the period to the year of 2020", Concepts of National Environmental Policy of Ukraine for the period to the year of 2020, approved by the order of the Cabinet of Ministers of Ukraine dated October 17, 2007, because up to now the activity of green business enterpreneurships has been managed only by the 
provisions of the law of Ukraine "On environmental protection". This legislation is essential for the activity of green business enterprises.

The main objectives of environmental policy are to keep the natural environment safe for the health of people; to raise public awareness about the issues of environmental protection to include an ecological component in economy sectors; to stop the losses of biological and landscape diversity; to establish an ecological network; to ensure environmentally-balanced use of natural resources and more. This will ensure the ecologization of industry; introduce new scientific achievements; produce energy effective and resource saving technologies; promote low-waste, waste-free and environmentally friendly technology processes; encourage high use of environmental audit and certifications of production.

Many factors are considered to create effective instruments of environmental policy: the solidary liability of the state and society for the state of natural environment, model changes to resource-intensive production, introduction of standards of control system for natural management, and increase in the role of ecological and economical instruments to regulate environmental protection and use of natural resources.

\section{Ecological enterpreneurship in agriculture: problems and prospects}

Development of ecological enterpreneurship in a country must take place in those fields, such as farming, that have considerable advantages. In Ukraine there is the highest level of arable land in Europe, however poor culture ofagriculture leads to destruction of soils. The modern state of the soil use does not meet the requirements of rational nature use.

According to the data from the source (Danylyshyn, 1999), area of soils of black earth type, including meadow black earth soils, in Ukraine is 22,83 million hectares, which presents $8,8 \%$ of world resources of black earth soils.

Most soils of Ukraine are characterized by exceptionally high natural fertility. The varieties of black earth soils prevail. Among them, the most fertile are the typical and regular black earth and south black earth. These varieties respectively occupy $18,1 \%, 27,7 \%$ and $8,9 \%$ of the total area of arable land of the country. Arable land accounts for up to $10 \%$ podzolic black earth, and about $6 \%$ for black earth and sod-skeletal soils. Large areas are occupied by the sod-podzolic (about 7\%), podzolic (5\%) and grey forest $(6,7 \%)$ soils, which are characterized by relatively high natural fertility. The brown (about 9\%), meadow (2\%), sod-gley $(1,3 \%)$, brownified $(0,4 \%)$ and other varieties of soils are also widespread (Zastavnyy, 1994).

According to the data from the Institute of land organization of the National Academy of Agrarian Sciences of Ukraine and the Institute for Soil Science and Agricultural Chemistry of the National Academy of Agrarian Sciences of Ukraine a structure of the soil cover of agricultural lands of Ukraine is shown in Table 1.

Table 1. Structure of the soil cover of agricultural lands of Ukraine (main groups of soils)

\begin{tabular}{lllll}
\hline \multirow{2}{*}{ Main groups of soils } & \multicolumn{2}{c}{ Agricultural land } & \multicolumn{2}{c}{ Including plough land } \\
\cline { 2 - 5 } & \multicolumn{1}{c}{ thousand ha } & $\%$ & thousand ha & $\%$ \\
\hline Sod-podzolic of different origin & 2522,2 & 6,03 & 2080,5 & 6,3 \\
\hline Clear-grey forest podzolic & 2149,3 & 5,1 & 1931,8 & 5,8 \\
\hline $\begin{array}{l}\text { Darkly-grey podzolic and podzolic black } \\
\text { earths }\end{array}$ & 4133 & 9,9 & 3858,1 & 11,6 \\
\hline Turf of different origin & 1281,2 & 3,06 & 536,7 & 11,6 \\
\hline Meadow of different origin & 1565,9 & 3,7 & 764,7 & 2,3 \\
\hline Meadow marsh and swampy soil & 716,5 & 1,7 & 99,4 & 0,3
\end{tabular}




\begin{tabular}{lllll} 
Peatbog & 614,6 & 1,5 & 82,2 & 0,2 \\
\hline Mocharic soils & 87,0 & 0,2 & 66,2 & 0,2 \\
\hline Black earths of different origin & 22111,5 & 52,8 & 19968,2 & 60,2 \\
\hline Meadow black earth & 718,9 & 1,7 & 567,5 & 1,7 \\
\hline $\begin{array}{l}\text { Solonetzs and saline soils of different } \\
\text { origin }\end{array}$ & 171,1 & 0,4 & 57,7 & 0,2 \\
\hline $\begin{array}{l}\text { Solodized and hearth soils } \\
\begin{array}{l}\text { Darkly-chestnut and chestnut of different } \\
\text { origin }\end{array}\end{array}$ & 301,4 & 0,7 & 223,9 & 0,7 \\
\hline $\begin{array}{l}\text { Brown forest soils, soddy-brownified, } \\
\text { podzolic-brownified soils }\end{array}$ & 1238,1 & 3,0 & 1136,1 & 3,4 \\
\hline Brown & 189,1 & 0,5 & 73,4 & 0,2 \\
\hline Warp & 127,2 & 0,3 & 71,4 & 0,2 \\
\hline Reclaimed & 658,2 & 1,6 & 347,7 & 1,05 \\
\hline Washed out, rock yields & 10,6 & 0,03 & 5,0 & 0,02 \\
\hline Brown rock & 119,1 & 0,3 & 17,0 & 0,05 \\
\hline Other & 322,9 & 0,8 & 74,7 & 0,2 \\
\hline Total in Ukraine & 2801,9 & 6,7 & 1226,0 & 3,7 \\
\hline
\end{tabular}

Source: www.zem.kiev.ua, www.issar.com.ua

The modern use of land resources of Ukraine does not meet the requirements of rational natural management, namely there is a violation of environmentally acceptable ratio of the areas of plough land, natural grasslands, perennial plants.

Negative natural and anthropogenic processes include: landslides, erosion, suffusion, deflation, karsts, mudslides, salinization, flooding, and surface subsidence. There is an occurrence of about 20 different natural and anthropogenic processes, dangerous for the population, in $80 \%$ of the city areas; dangers among them are flooding, landslides, abrasion, and karst. They often happen in Volyn, Ternopil, Khmelnytsk, Vinnytsya, Odesa, Kherson regions and the Autonomous Republic of Crimea. Eight hundred thousand hectares of land are flooded in 2240 urban areas, including 200 urban areas where landslides and karsts occur.

In the Ivano-Frankivsk and Zakarpattia regions and the Autonomous Republic of Crimea the mudslide process are taking place in $70 \%$ of mountain water intakes, mainly in a low-hill terrain. In Ukraine they affect $3-25 \%$ of the territory.

Over 17,0 million ha of agricultural lands, or $40,9 \%$ of their total area are affected by the water and wind erosion. The most eroded soils are in the Donetsk (70,6\%), Luhansk $(62 \%)$ and Odesa $(56 \%)$ regions. The eroded lands include 4,7 million ha of medium and heavily washed off lands, including 68 thousand ha of those, which have fully lost humus horizon. The annual increase of eroded lands area in Ukraine is about 80-120 thousand ha. Environmental damages due only to soil erosion exceed 9,1 milliard hryvnias (http: // www.ukrstat.gov.ua).

Technogenic pollution of soils depends on type, quantity of waste, radionuclides, pesticides and mineral fertilizers. Pollutants can affect low-buffer humus sod-podzolic soils. In an acidic environment they are transformed into more mobile compounds, and migrate to low layers and ground waters. In the conditions of neutral or alkaline environment on highbuffer soils (black earth, chestnut earth) contaminating elements are usually passive and difficult to access for the plants.

The soil contamination with the emissions from industrial enterprises and chemicalization in agriculture causes a considerable environmental damage to the land resources. In cities the common source of soil contamination with heavy metals is the enterprises of ferrous and non-ferrous metallurgy, light industry, and power plants. The risk of 
soil contamination is determined not only by the content of heavy metals but also a class of hazard of toxicants. Arsenic, Cadmium, Mercury, Selenium, Plumbum, Zinc, Fluorine, Benzopyrene belong to the first class of hazard; Boron, Cobalt, Nickel, Cuprum, Molybdenum, Antimony, Chrome belong to the second class; the third class of hazard includes Barium, Vanadium, Tungsten, Manganese, Strontium. Many of them can cause people's diseases.

Resistance of soils to contamination is designated by a ratio and depends on many factors: temperatures, steepness of slopes, stoniness, structure, specific resistance, mechanical composition, content of humus, type of the water regime, $\mathrm{pH}$ reaction, capacity of ions, afforestation, and arable land. The level of technogenic contamination depends on the degree of resistance of soils.

In Ukraine soil resistance increases in direction from north to south. Sod-podzolic soils of Polesye and the brown earth (dry steppe) have very low resistance to the environmental footprint; the black earth soils are the most resistant. We believe this explains why the Predniprovsk and Donetsk regions of Ukraine have higher resistance to the environmental footprint.

The area of meadows and pastures in Ukraine must increase by 2,7 times, and the forests by 1,8 times. Natural grasslands support the meat and milk cattle breeding industries around the world.

Farmlands exceed twice the areas of arable land, but in Ukraine the area of arable land is almost 5 times larger than its area of plough land. Ukraine has 6 times less per capita than at the average in the world. For comparison, in Germany this ratio is $31,8 \%$, in Great Britain $18,5 \%$, in China $-19,5 \%$, in the USA $-20 \%$.

Ukraine territory is the least afforested in Europe; today only $14,3 \%$ of it is covered with forest. Conversion of arable land to natural grasslands and afforestation will help optimize the structure of agricultural land, restore the balance between natural complexes (plough land, meadows, forest, water), and prevent erosive processes and negative impact of droughts, since the forests and natural lands not only do not expose themselves to erosion and droughts but also soften the impact of this phenomenon on agricultural crops. Foremost, the farmland should be converted to natural grasslands and afforestation on the slopes with impetuosity of 3 degrees or more (4329 thousand ha), plowed lands of hydrographical fund (1,5 million ha), lands for cattle farms and pastures (1 million ha).

Due to shortcomings in legislation, land resources are used inefficiently. The specific land tenure is very high in industry and transport. For example, 6.6 ha of land account for each notional unit of investment in the chemical industry, in non-ferrous metallurgy $-2,9$, petroleum industry $-2,3$, power plant $-2,5$, mechanical engineering - from 2,0 to 4,0 ha. Very high land capacity is in a mining industry $-42,9$ ha, a non-ferrous metals industry $-30,0$ ha, black metals industry $-23,9$, mining $-12,9$ hectare for each notional unit of investment (http: // www.ukrstat.gov.ua). The current official standards for allocation of land for the needs of industry, transport, energy in our country are 2,5 - 2,7 times higher than the standards, adopted in Western Europe.

Finding solutions to the problems of the soil contamination, land organization, exceed the sown areas and the state and government support will improve the state of land resources of Ukraine and create a basis for ecological agricultural entrepreneurship development.

\section{Ecologization of production}

An important element of development of ecological entrepreneurship is an ecologization of production, which will be implemented as component of the economy within the framework of conception of sustainable development. 
The general approaches to the ecologization of production, such as a reduction in the consumption of natural resources and minimization of environmental expenses are often considered. Reduction in the consumption of natural resources and an increase in efficiency of economic entities activity in the country's economy is the technical re-equipment of production and revision of approaches by setting prices on the end-use products. The environmental expenses of enterprises should be included in the price, and environmental risks should be considered. Demand structure must be reviewed to determine the direction of development of an ecologically balanced economy.

Two perspectives exist on the question of interaction between the economy and natural environment in ecological economy. A law of conservation of energy (the first law of thermodynamics), asserts that a flow of resources, coming into the economic system from the environment, must be equal to the flow of waste that returns to the environment as a result of economic activity. Since waste should be recycled (returning to production and personal use), only the non-recycled part of waste returns to the natural environment.

Waste recycling means saving primary resources and preventing pollution without having negative consequences for economic development. However, according to the law of entropy (second law of thermodynamics), recycling opportunities are limited. Energy is lost during the process of recycling of substances and natural forces. The root of problem for ecologization of the economy lies in minimization of ecological expenses of production. The modern structure of ecological expenses under existing economic and legal mechanism of natural management includes:

1) Current and capital expenses for realization of preventive nature protection measures;

2) Economic estimation of negative consequences of pollution and violation of components of the natural environment (economic loss, damage);

3) Payments for the emissions (discharge) of contaminants into the environment and waste disposal;

4) Payments for using natural resources;

5) Fines for environmental offence and payments of compensation of damage;

6) System of compensation payments to the population, living in severe environmental conditions (Semenenko, 1998, pp. 42-52).

All of the mentioned expenses can be included into two groups--preventive payments and compensation payments. All expenses, related to prevention of environment pollution, and the rational use of natural resources, belong to the first group. Economic loss, from the environment pollution, and inefficient use of natural resources are the basis of estimated expenses of the compensation group. Unfortunately, ecological and economical losses as a result of economic entities activity are not fully taken into account. Qualifying particular expenses as environment-oriented ones is governed by three main documents, which are "Recommendation on preparation of report, under the form 1 - ecological expenses "Report on ecological fees and current expenses on environmental protection", approved by the order of the State Statistics Committee of Ukraine on July 1, 2002 No. 253, "List of activity types, which belong to the nature protection measures", approved by the Cabinet of Ministers of Ukraine on September 17, 1996 No. 1147, and "Methodical recommendations on the formation of the production of products (works, services) in the industry" on February 2, 2001 No. 47. Therefore, improvements must be made in: the practice of accounting, accountability, information bases for environmental protection, methodology of grounds for economic decisions, and projects taking into account an ecological factor. The underestimation of ecological and economical losses, and neglect of ecological factors, result in eco-destruction processes with often irreversible consequences. 
The concept of "economic efficiency" and "social effectiveness" are inextricably connected with a concept of resource and ecological balance. Humans are a part of nature, but at the same time their activity is eco-destructive and contributes to deterioration of environment. According to the data of the State Statistics Committee of Ukraine, from 60 to 100 million tons of pollutants get into the air, water and land resources of Ukraine yearly. Almost a third part of water, which enters surface water objects is polluted; the fifth part of pollutants, which get into the environment from stationary sources, gets into the air; twothirds of created toxic wastes are deposited in the environment. As per one square kilometer of the country's territory 9,7 tons of pollutants are emitted into the air, and the toxic waste input is 4,9 thousand tons, that exceeds several times the ratio of the developed countries. The pollutants input in a calculation per capita presents the following numbers: into the atmosphere - 119 kilograms, surface water - 184, soils - $998 \mathrm{~kg}$ (Shevchuk, 2007).

\section{Eco-destruction processes}

The following types of eco-destruction processes, such as the use of natural resources, violate the quality of components of natural environment and processes, and have impact on people and biota. The use of natural resources is mainly narrowed down to two processes, extraction and exhaustion. Special attention is given to the extraction of non-recoverable natural resources (oil, gas, and coal). Today Ukraine is already experiencing shortages. Exhaustion of natural resources is associated with the performance of economic functions, which leads to decrease of nutritive content in soil etc.

Pollution is an integral part of the eco-destruction processes of violation of quality of components of natural environment. Among the large number of types of pollution, the most noticeable is the emission or formation of pollutants in the atmospheric air, water basins, and soils. The main anthropogenic sources of pollution of the atmosphere are thermal and power equipment, industrial enterprises, agriculture, and transport. Ukraine has considerable pollution in the atmosphere, especially in the industrially developed regions. The termination or significant reduction of work of many industrial enterprises has created a substantial reduction in emissions into the atmosphere of Ukraine over the last decade. The consequences on the atmosphere are increased $\mathrm{CO}$ and $\mathrm{CO}_{2}$ concentrations; emission of sulphur compounds into the atmosphere; emissions of freon, nitrogen, chlorine and fluorine compounds; emission of additional heat into the atmosphere. Increase of $\mathrm{CO}_{2}$ in the atmosphere is caused by two factors, the deforestation (which is typical for Ukraine), and the increasing $\mathrm{CO}_{2}$ emissions from fuel combustion.

Pollution in the air is not only dangerous to the health of people, but also causes great economic losses. The presence of sulphur compounds in the air accelerates the corrosion of metals, destroys of buildings, structures, cultural monuments, and deteriorates the quality of industrial products and materials. Atmospheric carbon dioxide accumulation, one of the main causes behind greenhouse effect, is increasing due to the Earth being warmed up by the sunrays.

The main pollutant of air in Ukraine is industry; it makes almost twice as many harmful emissions than motor vehicles (65\% and 35\% accordingly) do. Among industrial facilities the main pollutants of atmospheric air are the enterprises of heat power engineering (about $29 \%$ of all harmful emissions into the atmosphere). In general, 33, 25 and $23 \%$ of all pollutants, emitted into the atmosphere, are the activity results of power, metallurgical and coal industry, enterprises of chemical and petrochemical industry, $-2 \%$. The largest share of emissions $(79 \%)$ is generated in the Donetsk region.

Considerable sources of pollution include various types of waste, such as industrial, solid, domestic, and agricultural waste. Hard waste is an important ecological problem of the 
big cities. The amount of domestic waste grows constantly. The detrimental consequences of reckless and thoughtless formation of dumps create pollution in groundwater and soil.

The greatest concentrations of heavy metals are recorded in soils of the East and South regions of Ukraine, where it substantially exceeds sanitary regulations: plumbum - 2,5-3,6 times, zinc $-1,9-2,8$ times, nickel $-1,5-2,0$ times, manganese $-1,2-1,3$ times. The cumulative ratio of chemical pollution of soils in these territories ranges from 78,6 to 123,6 , which is considered to be a dangerous level to the health of population. The lowest (allowable) level of danger of soils to the health of population is recorded in some areas of the North (Zhytomyr, Chernihiv) and Western (Volhynia) regions (http://uk.wikipedia.org).

The pollution of water basins is a threat to the health of the population. The results of research show that the habitants of the south and east regions of Ukraine use water for domestic and drinking purposes that is overly mineralized and glassy, with significantly high concentrations of chlorides, sulfates, calcium, magnesium, plumb, chrome, and manganese. The share of analyses of chemical water composition, exceeding sanitary regulations provides the following numbers: heavy metals $-12,1-19,7 \%$, pesticides $-7,9-14,3 \%$, nitrates $-4,6-$ $8,2 \%$. A hygienical analysis has shown that the water with the least quality and most dangerous to health is consumed by the habitants of those areas (Donetsk, Odesa), where there is a combination of natural hydrochemical anomalies and a high degree of anthropogenic pollution in water sources. The most high-quality drinking-water, which is safe due to its chemical composition, is found in the Northern, Western and Central regions of Ukraine (http://uk.wikipedia.org).

One of the most serious problems that threat to the ecological entrepreneurship development is a radioactive contamination of the territory of Ukraine. In general, almost 5,9 million ha of lands are polluted, of which (3,5 million ha) are the agricultural lands, 1,5 million ha are the forests.

A number of ecological problems have to be solved to form a system of ecological entrepreneurship in Ukraine. The problems include the extensive use of all types of natural resources, a large number of powerful industrial complexes, inefficient carrying-out of agricultural activity, lack of scientifically-based plans of seeding, cultivation of crops, lack of long-term objective environment impact assessments for industrial development, power plants, transport, use of outdated equipment, and insufficient capacity of sewage treatment plants. In case of improper conduction of environmental assessments and the lack of effective systems of fines and penalties for pollution, significant environmental problems emerge.

In order to solve ecological problems and to ensure sustainable ecological and economical development, social consciousness of society is required. An ecological culture among consumers creates ecological consciousness. Ecological culture appears to be a regulator of ecological activity.

Ecological culture requires a degree of understanding and ethics to support nature, so ecological problems can be solved to improve the environment. The root principle of ecological culture combines the social and natural within one system. This promotes ecologization and harmonizes the social system.

\section{Conclusion}

The Ukrainian society needs to reconsider attitudes toward the environment and society, and encourage environmentally-oriented thinking and environmental entrepreneurship.

The root problems that hinder ecological enterpreneurship development in Ukraine include: lack of the legal regulations, vagueness of terms and terminology, and not enough support from the state. However, in Ukraine more entrepreneurs are interested in ecological 
enterprises despite the risks. In the article ecological entrepreneurship was defined as: an entrepreneurial activity involving the production of goods and provision of services; the implementation of works that do not harm the environment; and which contribute to environmental preservation and renewal while meeting the consumers' needs for ecological products.

With quantitative measurements by researchers and development of more environmental legislation, Ukraine's integration into the world economy requires permanent improvement of conceptions of ecological policy. Methods must be improved to encourage producers to change the model of resource-intensive production, introduce the standards of control system of natural management, and enhance the role of ecological and economical instruments for environmental protection and the use of natural resources.

The prospects of development of ecological enterpreneurship in agriculture has been researched. The results of conducted analysis show that subject to rational natural management and change in the culture of use of land and water resources, the country has considerable potential for agro-industry, which will increase in the future. Inertia tendencies in natural management and the technogenic approaches to the country's economy will not create enough natural resources to support ecollogicaly-balanced development.

Recently, the priority direction of development of ecological entrepreneurship, and solutions to rational natural management, is to work out economic methods for dealing with the issues by creating the system of personal economic interest and responsibility. The law of Ukraine "On environmental protection" pays much attention to the economic side of ecological relations, which is an important step forward. It scientifically proves the interdependence of ecological, economic and social interests of man, society and the state to ensure sustainable development and environmental protection. However, in Ukraine the economics and regulations meant to adjust environmental protection and natural management practices have not worked out well. Development of theory and practices of ecological and economical interactions and ecological expenses gain more importance. A major step forward development of ecological entrepreneurship is a formation of the Law of Ukraine "On basic principles (strategy) of the State Environmental Policy of Ukraine for the period to the year of 2020", Concepts of National Environmental Policy of Ukraine for the period to the year of 2020, which raises public awareness about the issues of environmental protection and environmental safety, improves the system of integrated ecological management by including an ecological component in the programs of development of economy sectors, ensures environmentally-balanced use of natural resources, and creates ecologization of production.

In order to provide real solutions to ecological problems, to bring problems of ecological entrepreneurship development in focus, and to create the sustainable economic development, it is necessary to evaluate the functioning of economic structures from ecological positions, and make needed adjustments. Environmental economists must identify and understand the causes of environmental capacity of economy and deal with them (rather than their consequences), promote efficient use of resources, encourage the search for new sources of energy, support of low-waste production and recycling, and work out a strategy of minimization of ecological expenses at the national level.

\section{References}

Basylevych, V.D. (2010), Ecological management and enterpreneuership: New prospective of ecological education, Education of Ukraine, no. 28, p. 6.

Basylevych, V., D. Walter, W. Hartmann and others (2010), Glossary of Green Business: ukrainian-german-russian-english, Kyiv: Znannya.

BMU/Roland Berger: GreenTech made in Germany 2.0. (2009), Munchen. 
Commercial Code of Ukraine, January, 16, 2003 N436-IV.

Concepts of National Environmental Policy of Ukraine for the period to the year of 2020, approved by the order of the Cabinet of Ministers of Ukraine dated October 17, 2007 // http://zakon. rada. gov.ua.

Danylyshyn, B.M., S.I. Doroguntsov, V.S. Mischenko and others (1999), Natural resource potential of sustainable development of Ukraine, Kyiv // www.lib.academy.gov.ua.

Eurostat. Data Collection Handbook on Environmental Goods and Services Sector. ICEDD for Eurostat - Unit E3. [Doc. ENV/EXP/WG/07 (2009)].

Galushkina, T. (2000), Economic instruments of ecological management (theory and practice), Odessa.

Kupalova, G. (2011), Ecological enterpreneuership as essential component of sustainable development of Ukraine, Journal of Taras Shevchenko National University of Kyiv, no. 26 , pp. 35-39.

Law of Ukraine "On basic principles (strategy) of the State Environmental Policy of Ukraine for the period to the year of 2020" (2011), // http://zakon. rada. gov.ua.

Melnyk, L., Melnyk, O., Burlakova, I. (2011), Ecologization of economic as prerequisite of sustainable development achievment, Kyiv: Center of ecological education and information.

OECD/EUROSTAT. The Environmental Goods and Services Industry: Manual for Data Collection and Analysis (1999), Published by: OECD Publishing Eurostat.

Prokopenko, O. (2012), Problems of management of innovation enterpreneiership of ecological direction, Sumy: Universytetska knyga.

Semenenko, B. (1998), Ecological expenditure in condition of economic transformation, Finance of Ukraine, no. 10, pp. 42-52.

Shevchuk, V. (2007), National ecological policy of Ukraine: strategical estimation and recommendations, Kyiv.

Stehnei, M., I. (2013), Ecological component of sustainable development of rural territories in Ukraine, Actual Problems of Economics, 148(10), pp. 171-176.

UNIDO, General Conference Thirteenth session, Vienna, 7-11 December 2009 Forum on industrial development issues Issues paper by the Secretariat Distr.: General 28 October 2009.

Vasilyeva, E. (2002), Environmental economics, Minsk: BGU.

Veklych, O. (2003), Economic mechanism of ecological regulation in Ukraine, Kyiv: Ukrainian institute of environmental research.

Zastavnyy, F. (1994), Georgaphy of Ukraine, Lviv: Svit.

http: // www.ukrstat.gov.ua

http: // www.ecopreneuring.biz

http://uk.wikipedia.org 